\title{
Study of Soil Fertility Status in Some Use of Rubber Plant Land in Pandeglang and Lebak Regencies, Banten Province
}

\author{
Andi Apriany Fatmawati, Nuniek Hermita \\ Department of Agroecoteknology, Faculty of Agriculture, \\ University of Sultan Ageng Tirtayasa \\ Jl. Raya Jakarta KM 04 Pakupatan Serang 42121, Indonesia
}

Aris Munandar, Mas Bayu Syamsunarno, Dodi Hermawan,

Lukman Anugrah Agung,

*Achmad Noerkhaerin Putra

Department of Fisheries, Faculty of Agriculture, University of Sultan Ageng Tirtayasa

Jl. Raya Jakarta KM 04 Pakupatan Serang 42121, Indonesia

*e-mail: putra.achmadnp@untirta.ac.id

\begin{abstract}
This research aims to determine soil fertility in some rubber plantations area. This research is expected to be used as basic information in increasing the production of rubber plants. This research was conducted in Banjar Village, Pandeglang Regency and Wanasalam Village, Lebak Regency, Banten Province. In the research location, 2 soil samples were taken and then analyzed at the Agro-climate and soil Laboratory, Faculty of Agriculture, Sultan Ageng Tirtayasa University. The parameters tested included $\mathrm{C}$-Org, $\mathrm{N}$-Total, $\mathrm{pH}, \mathrm{P}$, and $\mathrm{K}$. The results of the analysis in the Laboratory showed that some of the soil chemical properties in the research location had low nutrient content and availability. This is due to the $\mathrm{pH}$ of the soil at the research location classified as quite sour. The determination results of the soil C-organic content at the research location from each location were classified as low with values ranging from 0.1 to 0.4 . $P$ and $K$ content of both locations is classified as medium-low.
\end{abstract}

Keywords: Soil Fertility, Rubber plant, Production

\section{INTRODUCTION}

The land is a physical environment that made up of climate, relief, soil, water and vegetation as well as objects above it as long as there is the effect on land use [1]. Land use is closely related to crop productivity. In the field of plantations, for example in crop cultivation, soil conditions and management are important factors that will determine the growth and yield of crops cultivated. This is because the soil is a growing media for plants, as a warehouse and supplier of nutrients elements. Soil-based on its particle size is a mixture of sand, dust, and clay. The finer the particles get, will produce a wider particle surface area per unit weight. Thus, clay is the most extensive soil fraction compared to the other 2 fractions. On the surface of this particle, various chemical reactions of the soil occur, which then affect soil fertility [2].

Soil fertility is the potential of the soil to provide sufficient amounts of nutrients in an available and balanced form to ensure maximum plant growth. However, it can't be assumed that fertile soil is also productive because soil fertility status does not provide an indicator of the sufficiency of other growth factors [3]. Rubber plants are one of the many plantation crops in Pandeglang Regency. Based on BPS, 2018 there was a decrease in the area of rubber plantations known in
2016 to $4,834 \mathrm{Ha}$ and in $20174,112.81 \mathrm{Ha}$. The more decreasing number of rubber fields, then it is difficult to expect farmers to produce optimally. The decrease in land area is estimated due to the conversion of plantation land to nonplantations. Other than that, the decreasing in rubber production was also caused by low soil fertility.

Based on these problems, to improve soil fertility at the research location into productive land, basic information is needed to increase rubber production on soil problems that affect crop production and the condition of soil fertility. Therefore, it is necessary to study soil fertility status on some plant land use Rubber in Pandeglang Regency, Banten Province.

\section{RESULT AND DISCUSSION}

The value of total-N, phosphorus, Kalium, $\mathrm{pH}$ and $\mathrm{C}$ organic is shown in Table 1.

Table 1. Total-N, phosphorus, Kalium, $\mathrm{pH}$ and $\mathrm{C}$ organic of soil in Banjar and Wanasalam.

\begin{tabular}{|l|l|l|l|l|l|l|}
\hline Location & $\begin{array}{l}\text { N- } \\
\text { Total }\end{array}$ & $\mathbf{P}$ & $\mathbf{K}$ & $\mathbf{p H}$ & $\begin{array}{l}\text { C- } \\
\text { Organik }\end{array}$ & $\begin{array}{l}\text { P- } \\
\text { available }\end{array}$ \\
\hline Banjar & 0.12 & Low & Medium & $\begin{array}{l}\text { Rather } \\
\text { acidic }\end{array}$ & Low & 3.51 \\
\hline Wanasalam & 0.07 & medium & medium & $\begin{array}{l}\text { Rather } \\
\text { acidic }\end{array}$ & Low & 29.51 \\
\hline
\end{tabular}

\section{Water content}

In general, the soil water content in three days after rain shows conditions below field capacity. This can be due to the relatively small rain that occurred before so that the contribution to groundwater is not too large and causes not all pores of the soil to be filled with water. The availability of water in the soil greatly affects plant growth directly. In dryland cultivation, the main source of water for plant growth is rain. Variation of rain, both in quantity, intensity, and time of rain; can be the cause of the difficulty to predict the right time to plant/adjust the cropping pattern. The differences of land use can affect the physical properties of the soil which in 
future can affect the properties of water retention and water movement in the soil. These differences cause differences in the dynamics of soil water content. As well with different rainfall quantity and intensity which also affects the dynamics of water content in the soil.

\section{N-Total content}

Nitrogen is the main macronutrient that is very important for plant growth, but the amount of nitrogen in the soil is low while the amount of transport carried out by the plants is quite high every season. $\mathrm{N}$ is absorbed by plants in the form of $\mathrm{NO}^{3-}$ (Nitrate) or $\mathrm{NH}^{4+}$ (Ammonium) [4]. The results of research on soil $\mathrm{N}$ content are presented in Table 1 . We can be seen that the soil nitrogen content in rubber land in Banjar with a value of 0.12 and in Wanasalam with a value of 0.07 . Based on these values, both locations indicate that $\mathrm{N}$-Total is low. The high and low of available nitrogen in the soil for plants very determine crop production. Addition of nitrogen in organic and inorganic forms mainly will give an increase in crop yield in the amount that supports plant growth. Factors that affecting $\mathrm{N}$ availability are micro-organisms, both those that live freely and those that are associated with plants. Another addition of soil nitrogen is due to a jump of electricity in the air. Nitrogen can enter through rainwater in the form of nitrates. This number is very dependent on place and climate [5]. Meanwhile, according to [6], about $90 \%$ of nitrogen in the soil is organic nitrogen in organic matter. Organic ingredients and nitrogen deserve special attention because their small amounts naturally are easily lost through oxidation, washing and uptake of plants.

\section{$P$ and $P$ content available.}

Phosphorus $(\mathrm{P})$ is the second nutrient after nitrogen $(\mathrm{N})$ which is needed by plants for good and normal growth. The availability of $\mathrm{P}$ elements in the soil is largely determined by the nature and type of soil. The P Element plays a role in the formation of seeds and fruit [2]. The results of the study regarding the phosphorus content $(\mathrm{P})$ of the soil at the research locations in Banjar has low criteria and $\mathrm{P}$-available value of 3.51 while in Wanasalam has the medium criteria and Pavailable values 29.51 . The availability of $\mathrm{P}$ in the soil is very affected by $\mathrm{pH}$ values. The $\mathrm{pH}$ values at both study locations were ranging from 5-6 which were classified as somewhat acidic. According [7] that at neutral $\mathrm{pH}$ conditions the $\mathrm{P}$ content is usually also in the high criteria, because ion exchange complexes are dominated by alkaline cations due to a neutral $\mathrm{pH}$ atmosphere, so the nutrient exchange is quite effective because, at neutral $\mathrm{pH}$, the availability of nutrients is optimal. Other than that, the low P content can also be caused by the low content of organic matter in the soil at the study site.

\section{K content}

Potassium $(\mathrm{K})$ is one of the important macronutrients for plant growth and development. Potassium has the role of the activator of several enzymes in plant metabolism. Potassium plays a role in the synthesis of proteins and carbohydrates and increases photosynthetic translocation to all parts of the plant [8]. Based on the results of the research in these two locations the $\mathrm{K}$ value was classified as medium. The availability of $\mathrm{K}$ in the soil very depends on external additions.

\section{PH content}

The acidity level of the soil in the two study locations ranged from 5-6, which included rather sour. It is seen that the $\mathrm{pH}$ in each plantation centre area is suitable for rubber plants so that farmers do not need fertilization. This is matching with Setyamidjaja's study, 1999 that rubber plants are suitable for soil acidity ranging from 3.0-8.0 but not suitable at $\mathrm{pH}<3.0$ and $>\mathrm{pH}$ 8.0. The properties of soil that suitable for rubber plants, in general are sufficient NPK nutrient content, not lacking micronutrients, and $\mathrm{pH}$ range between 4.5-6.5

\section{C-Organic Content}

Organic C-level is a chemical level that can be used simply to determine the characteristics of soil organic matter. The results of the determination of soil C-organic content from each study location are low. This shows that there is no addition of organic materials specifically for planting cover crops (legume cover crop). In general, farmers control weeds on plantations using herbicides or lawn mowers, so the organic content is low. Low C-organic content indirectly shows the low production of organic material in the research soil, because soil organic matter is one of the parameters that determine soil fertility. Organic matter has an important role in determining the ability of the soil to support plants. Therefore, if soil organic matter content decreases, the ability of the soil to support crop productivity also decreases [9].

\section{CONCLUSION}

Some of the soil chemical properties in the research location had low nutrient content and availability. This is due to the $\mathrm{pH}$ of the soil at the research location classified as quite sour. The determination results of the soil C-organic content at the research location from each location were classified as low with values ranging from 0.1 to 0.4 . $\mathrm{P}$ and $\mathrm{K}$ content of both locations is classified as medium-low.

\section{ACKNOWLEDGMENT}

This research was funded by research grant IDB with the scheme of Penelitian Dasar Unggulan Iptek.

\section{REFERENCES}

[1] Arsyad. 1989. Konservasi Tanah dan Air. Bogor. Penerbit IPB

[2] Hanafiah, Kemas Ali. (2005). Dasar-Dasar Ilmu Tanah. Jakarta: Raja Grafindo Persada

[3] Anna K., J.L. Nanere, Arifin, S.R. Solo, Ramualdus, Lalopua, Bachrul, [4] Rosmarkam and Yuwono, 2002. Ilmu kesuburan tanah. Kanisius: Yogyakarta.

[5] Hakim, N., M.Y. Nyakpa., A.M. Lubis., S.G. Nugroho., M.R. Saul., M.A. Diha., G.B. Hong., dan H.H. Bailey. 1986. Dasar Dasar Ilmu Tanah. Unila, Lampung. 
[6] Foth. 1990. Dasar-Dasar Ilmu Tanah. Erlangga: Jakarta. $207 \mathrm{hl}$

[7] Prabowo, R. (2010). Kebijakan Pemerintah Dalam Mewujudkan Ketahanan Pangan Di Indonesia. Jurnal mediagro. Vol 6. No 2. Hal: 62 -73 .

[8] Marschner 1995. Marschner, H 1995, Mineral nutrion of higher plants, Second edition, Academic Press, London.

[9] Nurmegawati, Afrizon, and Dedi Sugandi, 2014. Kajian Kesuburan Tanah Perkebunan Karet Rakyat di Provinsi Bengkulu. Jurnal Littri 20 (1), Hlm 17-26. 